\title{
Stav judaizma prema životinjama u starozavjetnim spisima Biblije, u židovskome pravu i u rabinskoj literaturi
}

Agnes Eva DaDon*

dadonagi@gmail.com

Kotel DaDon***

kdadon@gmail.com https://doi.org/10.31192/np.16.3.3

UDK: $26: 179.3$

179.3:26-254

179.3:26-24

Izvorni znanstveni rad / Original scientific paper Primljeno: 14. lipnja 2018. Prihvaćeno: 4. srpnja 2018.

Članak analizira stav judaizma prema životinjama te nekim ključnim pitanjima vezanim uz tu tematiku kao što su: vegetarijanstvo i mesna prehrana, slučajevi u kojima je dopušteno ozlijediti životinju, odnos prema opasnim životinjama, lov u judaizmu, borba s bikovima, način na koji se moderna prehrambena industrija odnosi prema životinjama. Članak također donosi prijedloge za uvođenje promjena. Posljednji dio govori o stavu judaizma prema posjetu zoološkom vrtu. U radu autori prvo daju uvodno objašnjenje o sućuti i dobrom odnosu prema životinjama u židovstvu. U drugom dijelu članka, autori analiziraju maloprije spomenute teme u starozavjetnim spisima Biblije, u židovskome pravu i rabinskoj literaturi od talmudskih vremena do danas. Autori raščlanjuju ova pitanja na temelju niza izvora iz rabinske literature i responsi, od talmudskih vremena preko srednjega vijeka sve do suvremenih rabina, literature koja je sada prvi put prevedena na hrvatski jezik. Tekstove su s hebrejskoga $i$ aramejskog preveli autori članka. U članku autori pokazuju da je životinjski život vrijedan jer je $i$ on djelo Božje te ga stoga nije dopušteno ugrožavati ili bespotrebno oduzimati. No, dođu li u sukob životinjski i ljudski život, ljudski život svakako ima prednost pred životinjskim životom.

Ključne riječi: responsa, halaha, rabin, životinje, sućut.

\footnotetext{
* Agnes E. DaDon, lektorica hebrejskog jezika, Katedra za judaistiku, Filozofski fakultet, Sveučilište u Zagrebu, Ivana Lučića 3, HR-10000 Zagreb.

**Doc. dr. sc. Kotel DaDon, Katedra za judaistiku, Filozofski fakultet, Sveučilište u Zagrebu, Ivana Lučića 3, HR-10000 Zagreb; glavni rabin Židovske vjerske zajednice Bet Israel u Hrvatskoj.
} 


\section{Uvod}

Od vremena do vremena svjedočimo slučajevima zlostavljanja životinja od kojih neki graniče s okrutnošću. Društvena i kulturna situacija izravno je povezana te utječe na stav pojedinaca i mnoštva prema životinjama. Zbog toga sve veći broj raznovrsnih pravnih sustava sve odlučnije uvodi zabranu zlostavljanja životinja. Svrha ovoga članka jest izložiti stav židovskoga zakona, temeljen na mnoštvu izvora iz židovske baštine koji jasno prikazuju iskrenu sućut prema životinjama i neupitno zahtijevaju da se o životinjama vodi briga.

U ovoj raspravi razmotrit ćemo stav židovskoga zakona vezan uz ispravno postupanje prema životinjama. Židovski zakon već je u biblijskim vremenima vodio računa o odnosu čovjeka i životinje. Postoji opsežan korpus halahičke literature koja se bavi pitanjem sućuti prema životinjama te čini temelj analize ispravnog odnosa prema životinjama, čak i za moderna pitanja kao što su eksperimentiranje na životinjama te mnoga druga. Većinom je to opterećeno raspravom o pronalasku ravnoteže između želje da se izbjegne patnja životinje $\mathrm{s}$ jedne strane, te raznih ljudskih interesa, s druge strane.

U ovom radu također ćemo se baviti i posebnim pitanjima, kao što je stav judaizma prema vegetarijanstvu, zatim kada je, prema židovskom zakonu, dopušteno povrijediti životinju i do koje mjere te o stavu prema opasnim životinja ma. Osim toga, istaknut ćemo i stav židovskog zakona prema problematičnim pitanjima kao što su lov radi sporta te borba bikova. Konačno, dotaknut ćemo i temu industrije hrane koja se temelji na životinjama te ponuditi neka praktična rješenja i ukazati na probleme kojima se treba pozabaviti, a koji izviru iz židovskih izvora.

\section{Sućut i dobrota prema životinjama}

Postoji talmudska debata ${ }^{1}$ o tome je li zabrana nanošenja boli životinji biblijskog ili rabinskog podrijetla. Ista se debata nastavila i u posttalmudskoj rabinskoj literaturi, ali većina rabinskih autoriteta smatra da je riječ o biblijskoj zabrani. ${ }^{2}$ Jedan od izvora iz Biblije koji ukazuju na biblijsko podrijetlo ove zabrane nalaže pomaganje neprijateljevom magarcu, koji je pao pod teškim teretom: "Ako opaziš magarca onoga koji te mrzi kako je pao pod svojim tovarom, nemoj ga ostaviti: zajedno s njegovim gospodarom moraš mu pomoći

\footnotetext{
${ }^{1}$ Vidi: Babilonski Talmud (dalje: BT), Bava Mecia 32b, Bnei Brak, Vilnius - Machon Tevel, 1961. (dalje: Vilne).

2 Vidi: A. STEINBERG, Assia, Jerusalem, 1989, I, 263-269.
} 
da se digne« (Izl 23, 5). ${ }^{3} \mathrm{U}$ nastavku navodimo neke biblijske izvore čiji je cilj sprječavanje mučenja životinja:

a) Zabranjeno je oranje uz istodobno uprezanje goveda i magarca ili nekih drugih različitih životinja. ${ }^{4}$

b) Zabranjeno je ometanje životinje pri hranjenju. ${ }^{5}$ Rabin Aharon Halevi iz Barcelone, ${ }^{6}$ u knjizi Hinuh (Pouka), duboko zalazi u ljudsku psihu da bi objasnio razmišljanje koje stoji u potki ove zabrane:

»Iz temelja ove zapovijedi moramo sebe poučiti da naša duša mora biti dobra i da mora izabrati ono što je ispravno, toga se držati i činiti djela milosrđa i dobrote. A kada se na to naviknemo - čak i kada je riječ o životinjama, stvorenima da bi nam služile, moramo sviknuti da ih namirimo dijelom kojeg su zaslužile vlastitim radom - duša će se naviknuti da se i prema drugima ponaša jednako; činiti dobro ljudima i paziti da im ne oduzmemo ono što im je primjereno, te ih nagraditi u skladu s učinjenim dobrom i namiriti ih onim za što su radili. I primjereno je da tako čini sveti izabrani narod. $^{7}$

c) Obvezno je nahraniti životinju prije nego ćeš sam jesti. ${ }^{8}$ Postoje neslaganja oko toga ima li zapovijed da se životinja nahrani prije negoli čovjek počne jesti snagu zakona ili je to samo pobožan običaj. Majmonid smatra, kako se čini, da je riječ o pobožnom običaju, ${ }^{9}$ dok kasniji znalci smatraju da naredba ima snagu zakona. ${ }^{10}$ Stoga, ljubimce, koji ovise o svojim gospodarima, treba nahraniti prije negoli čovjek sjedne jesti.

d) Mnoštvo izvora opisuje Božju skrb pri hranjenju svih životinja, od najmanjih do onih velikih. ${ }^{11}$

${ }^{3}$ Jure KAŠTELAN, Bonaventura DUDA (gl. ur.), Sveto pismo Staroga i Novoga zavjeta, Zagreb, Kršćanska sadašnjost, 2008. U slučajevima kada taj prijevod koristi tetragramom JHVH, autor ga je zamijenio imenima Vječni, Gospodin ili Gospod, jer u židovstvu nije dopušteno izgovarati Božje ime JHVH.

${ }^{4}$ Pnz 22, 10; BT Bava kama 54b (Vilne).

${ }_{6}^{5}$ Pnz 25, 4; BT Bava kama 54b (Vilne).

${ }^{6}$ Aharon Halevi, rabi (Barcelona, 1234.-1300.) - Prijatelj i sugrađanin rabi Šeloma ben Avrahama Adereta - Rašbe, s kojim je zajedno studirao kod rabina Mošea ben Nahmana - Nahmanida i kod rabenu Jone. Autor mnogih knjiga, između ostaloga komentara Talmuda i djela rabina Jichaka Alfasija - Rifa, no nedvojbeno mu je najznamenitija knjiga vodič o zapovijedima (micvama) Sefer haHinuh (»Knjiga odgoja«), koja nabraja 613 zapovijedi (micvi) iz Tore prema kriterijima koje je odredio Majmonid, te prema redoslijedu paraša. Napisao ju je kao vodič u ispunjavanju zapovijedi (micva) za svoga sina koji se bližio dobi bar micve. Tiskana je u Veneciji 1523. godine, a od tada je ponovno tiskana u mnogo izdanja na raznim mjestima.

7 Rabin Aharon HALEVI, Sefer HaHinuh, Jeruzalem, Eškol, 1996, 778, micva 596; vidi i BT Baba Mecia 89a (Vilne); s heb. prev. autori članka.

${ }^{8}$ Pnz 11, 15; BT Berahot 9a, Jeruzalem, Steinsaltzovo izd. 1999. (dalje: Steinsaltz).

9 MAJMONID, Mišne Tora, Jerusalem, 1974, Jad Ha-Hazaka = Mišne Tora (dalje MT) Hilhot Avadim 9:8.

${ }^{10}$ Magen Avraham u Orach Chaim 167:18, Mišna Berura u 167:40 i drugdje.

${ }^{11}$ Mehilta DeRabi Išmael, Mišpatim 20: BT Avoda Zara 3a (Vilne). 
e) I životinja se mora odmarati na šabat. ${ }^{12}$

f) Zapovjeđeno je da se životinja-majka udalji dok se uzimaju njezina jaja ili pilići. ${ }^{13}$

g) Zabranjeno je istoga dana zaklati životinju i njezino mladunče. Rabin Aharon Halevi iz Barcelone ovako to objašnjava:

»Zabrana klanja životinje i njezina mladunca istoga dana - bez obzira na to je li riječ o posvećenoj ili običnoj životinji - kako je pisano: 'Ne koljite krave ni ovce $u$ isti dan s njezinim mladim' (Lev 22, 28) (...) ima svoj korijen u naredbi da svaki čovjek u svojem srcu mora shvatiti da se briga Božja, neka bude blagoslovljen, prostire nad svim vrstama životinja. I, zahvaljujući njegovoj brizi one će živjeti zauvijek; jer je njegova briga u stvarnosti njihova hrana. Stoga niti jedna životinjska vrsta nikada neće u potpunosti izumrijeti. Iako je njegova briga za ljudsku vrstu osobnog karaktera (...) A o tome možemo govoriti i iz kuta jednostavnog razumijevanja da će takav pristup u našim dušama učvrstiti osobinu suosjećanja i udaljiti nas od osobine okrutnosti - koja je loša osobina. Stoga, iako nam je Bog dopustio [da jedemo] neke vrste životinja radi vlastitog preživljavanja, [također] nam je naredio da ne ubijemo životinju i njezino mladunče istoga dana da bi u našim dušama učvrstio svojstvo sućuti. « ${ }^{14}$

h) Zapovijeđeno je da ne smijemo jesti životinju dok nije potpuno mrtva. ${ }^{15}$ Ta zabrana jedna je od »sedam zapovijedi sinovima Noinim $« .{ }^{16}$ Ova zabrana jedino je prehrambeno pravilo namijenjeno ostalome čovječanstvu, dok su židovskome narodu dani mnogi i složeni zakoni kašruta. Takva okrutnost postoji i danas u nekim zemljama na Dalekom Istoku gdje je popularno jesti životinje dok su žive. Rabin Aharon Halevi iz Barcelone objašnjava:

»Zabranjeno nam je jesti ud žive životinje tj. ud kojega smo životinji odrezali dok je još bila živa. O tome je rečeno: 'Samo, pazi da ne jedeš krvi! Ta krv je život.' Tako je rečeno: 'Ne smiješ jesti život s mesom.' - To je ud žive životinje.' (Pnz 12, 23) (...) Ova zabrana dolazi od korijena zapovijedi [čija je svrha] da ne postanemo okrutni jer to je naodvratnije svojstvo. I, uistinu, nema veće okrutnosti na svijetu od okrutnosti onoga tko reže ud ili meso životinje dok ona pred njim još stoji živa te ga jede. I, već sam mnogo puta pisao [o] velikom dobru koje dobivamo prihvaćanjem dobrih osobina i udaljavanjem od loših svojstava, jer

${ }^{12}$ Izl 20, 10; BT Šabat 153b (Steinsaltz).

${ }^{13}$ Pnz 22, 6-7.

${ }^{14}$ Rabin Aharon HALEVI, Sefer HaHinuh, Micva 294, 385; vidi još u BT Hulin 78a (Vilne); MT hilhot Šehita 12; s heb. prev. autori članka.

${ }^{15}$ BT Sanhedrin 59a (Vilne).

${ }^{16}$ Sedam zapovijedi Noinim sinovima - hebr. ševa micvot bene Noah; sedam odredaba (šest zabrana i jedna obveza) za praktičan život čovječanstva, koje djelo cijelo potječe od Noe: zabrana idolopoklonstva, zabrana proklinjanja Boga, zabrana krvoprolića, zabrana »otkrivanja golotinje« (održavanja zabranjenih spolnih odnošaja), zabrana krađe, obveza osnivanja sudova, te zabrana jedenja mesa još žive životinje; vidi još o sedam zapovijedi sinovima Noinim u: Kotel DaDon, Židovstvo. Život, teologija i filozofija, Zagreb, Profil, 2009, 351-357. 
dobro se dobra drži. A dobri Bog želi da činimo dobro te nam je stoga zapovjedio da izaberemo dobro. Takav je moj pristup većini zapovijedi, u skladu s njihovim jednostavnim razumijevanjem. ${ }^{17}$

j) Zabranjeno je jesti krv. ${ }^{18}$ Čak ni krv koju pronalazimo u jajetu, zametku, nije dopušteno konzumirati. ${ }^{19}$ Ovako objašnjava Rabin Aharon Halevi iz Barcelone:

»Ne jedemo krv [domaće] životinje, [divlje] životinje ili ptice jer je rečeno: 'Ne smijete uživati krvi ni od ptica ni od stoke ni u kojem svome prebivalištu.' (Lev 7, 26). (...) Zabrana konzumiranja krvi ponavlja se na mnogim mjestima u Tori (...) Čini mi se na razini jednostavnog shvaćanja zabranjene hrane (...) Ali, također je to moguće reći i o krvi zbog čije konzumacije, uz loš ustroj [kojeg donosi] - jer i sama potječe od lošeg ustroja - pomalo bismo stjecali i svojstvo okrutnosti. Dok čovjek guta dijelove živih bića, kao što je i sam, unosi u tijelo onaj dio životinje o kojem život uistinu ovisi i s kojim je povezan njihov duh. Dobro je, naime, poznato da zvijeri imaju duh kojeg mudraci nazivaju živim duhom, što znači da nije riječ o inteligentnom duhu. Također možemo vidjeti i da njihov duh ima svojstvo koje životinje čuva od padanja u zamku te u neke druge situacije. A Nahmanid, neka blagoslovljena bude uspomena na njega, napisao je $(o$ Lev 17,11$)$ vezano uz razlog krvi, da je dobro poznato kako se ono što je pojedeno vraća (nastavlja živjeti) u tijelu onoga koji je pojeo. I [stoga], ako čovjek pojede krv, u njegovu duhu zavladat će tupost i grubost, baš kako je tupa i gruba zvijer. Osim toga, još je napisao nešto slično onome što sam i ja rekao - nije primjereno da duh jede duh. $\aleph^{20}$

k) Grdnja Bileama koji je izbatinao svojega magarca. ${ }^{21}$

l) Talmud kaže da je dopušteno prekršiti rabinsku zabranu na šabat kako bi se spriječilo nanošenje patnje životinji i olakšalo hranjenje životinje koja je zapela u kanalu za vodu. ${ }^{22}$

Ima još mnogo zapovijedi koje pokazuju da je suosjećanje sa životinjama put Tore. Majmonid vjeruje da je svrha svih ovih zapovijedi zaštita životinja od patnje koju one proživljavaju jednako kao i ljudi. ${ }^{23}$ Nahmanid, ${ }^{24} \mathrm{~s}$ druge strane,

${ }^{17}$ Rabin Aharon HALEVI, Sefer HaHinuh, Micva 452, 620; vidi još u BT Traktat Hulin 102 (Vilne); s heb. prev. autori članka.

${ }^{18}$ Post 9, 4; Lev 3, 17; 7, 26-27; 17, 10-12; Pnz 12, 22-25.

${ }^{19}$ Šulhan Aruh (dalje ŠA), Ketuvim (Jeruzalem, 1992), Jore Dea 66, 2-3; Responsa Igrot Moše (New York, 1973); Jore Dea I, 36; Sefer HaHinuh, Micva 148, 196.

${ }^{20}$ Rabin Aharon HALEVI, Sefer HaHinuh, Micva 148, 195; vidi još u BT Hullin 71a (Vilne) i BT Karetot 20b (Vilne); s heb. prev. autori članka.

${ }^{21} \mathrm{Br}$ 22, 28-34; vidi i Rabi Moše ben MAJMON - Majmonid, More Nevuhim, Jeruzalem, 1960. (prev. s arap. na hebr. rabi Jehuda Ibn Tibon). Mossad Harav Kook, Jeruzalem, 1977. (reprint izdanja iz Vilniusa, 1909.) III, 17.

${ }^{22}$ BT Šabat 128b (Steinsaltz).

${ }^{23}$ Vidi i MAJMONID, More Nevuhim III, 48.

${ }^{24}$ Moše ben Nahman, rabi, skraćeno: Ramban, poznat i kao Nahmanid (Gerona, Španjolska, 1194. - Izrael, 1270.) - Znameniti rabin svoga doba s velikim znanjem u mnogim područjima: 
kaže da je njihova svrha zaštititi osobu da joj duša ne bi bila uništena niti se srozala u okrutnost..$^{25}$ Različiti izvori govore o tome da se prema životinjama treba odnositi kao prema osobama, pojedincima, i da se pažljivo treba skrbiti o njihovim potrebama. Upravo to učimo iz stiha: »Pravednik pazi i na život svog živinčeta« (Izr 12, 10). Slavni midraš opisuje Mojsija i Davida kao predane pastire koji posvećuju pažnju svakoj životinji u svojem stadu. ${ }^{26}$ To svojstvo njihova karaktera pokazalo je Bogu da su vrijedni postati vođama Izraela.

»'Mojsije pasao ovce...' (Izl 3, 1) Bog provjerava bogatstvo kako je rečeno: 'Gospod proniče pravednika... ${ }^{27}$ (Ps 11,5$)$. [na koji ga način proniče?] U brizi za stado. Bog je iskušao Davida pomoću njegova stada i otkrio da je David dobar pastir, kako je rečeno: 'Izabra Davida, slugu svojega, uze ga od torova ovčjih' (Ps 78, 70). Zatvorio je velike ovce i pustio male da prve pasu ('mekšu travu'); zatim je na pašu poslao starije ovce (na 'srednje tvrdu travu'); i tek je na kraju na ispašu pustio najsnažnije ovce koje su pasle najtvrđu travu. Kada je to Bog vidio, rekao je: 'Onaj koji zna kako napasati ovce, svaku prema njezinim potrebama, neka pase i moj narod.' I Mojsija je Stvoritelj iskušao pomoću ovaca... Naši su učitelji rekli: Jednom, dok je Mojsije, naš učitelj, napasao [punčeve] Jitrove ovce, jedna ovca mu je pobjegla. Mojsije je trčao za njom sve dok ovca nije stigla do malog, sjenovitog mjesta. Tamo je janje pronašlo bazenčić vode i počelo piti. Dok se Mojsije približavao janjetu, rekao je: 'Nisam znao da si pobjegao jer si bio žedan. Tako si iscrpljen!' Zatim je janje podigao na svoja ramena i odnio ga natrag. Presveti je na to rekao: 'Kada se s tolikom ljubavlju brineš za ovce drugih ljudi - životom ti se kunem da ćeš biti pastir mojih ovaca, Izraela.' Zato je rečeno: 'Mojsije je pasao ovce...' ${ }^{28}$

Ovi primjeri, kao i mnogi drugi, ukazuju da je zabranjeno odnositi se prema životinji bez osjećaja za njezinu patnju i potrebe. Sljedeći talmudski izvor ukazuje na to da moramo suosjećati čak i s najnižim životinjama i biti prema njima milosrdni:

znanosti, filozofije, jezika i medicine. Bio je suvremenik Majmonida, među njegove studente ubrajaju se rabi Šelomo ben Avraham Aderet i rabi Aharon Halevi. Napisao je komentar na Toru i sastavio i halahičke knjige. Među prvima se bavio kabalom, a i njegovi su spisi pod utjecajem kabale. Godine 1267. morao je izbjeći iz Španjolske zbog javne rasprave s otpadnikom od židovstva Pablom Christianijem, na što su ga bili natjerali katalonski kralj i crkvene vlasti, koji su, dakako, presudili u korist preobraćenika. Kada mu je bilo 73 godine preselio je u Izrael, prispio u Jeruzalem, gdje je obnovio židovsko naseljavanje, jer su grad prije toga razorili Tatari. Do danas u starome gradu djeluje sinagoga koju je osnovao i koja nosi njegovo ime. Stoga ga se naziva i ocem modernoga naseljavanja Jeruzalema. Zbog teškoga života i nemogućnosti zarađivanja za život, otišao je u obližnji Ako, u kojemu je osnovao ješivu u kojoj je ostao do kraja života.

${ }^{25}$ NAHMANID komentar (Mikra’ot Gedolot, Jeruzalem, 1959, Beč, 1859), Pnz 22, 6.

${ }^{26}$ Midraš - tumačenje; komentari Tore; dvije su vrste midraša: agadički (pripovjedački) i halahički (propisujući); prikupljeni u zbirkama (vidi još o Midrašu u DaDon, Židovstvo..., 503-505).

${ }^{27}$ Varaždinska biblija, Varaždin, Hrvatski biblijski nakladnik, 2012.

${ }^{28}$ Midraš Šemot Raba 2,2, Jeruzalem (reprint izdanja iz Vilniusa 1878.); s heb. prev. autori članka. 
»Rabijeve ${ }^{29}$ muke $^{30}$ djelom su došle i djelom su otišle. Djelom su došle kada je tele, koje su doveli na klanje, prišlo i podvuklo glavu pod Rabijeve skute, te počelo plakati. Rabi je rekao: 'Idi, jer za to si stvoreno!' Na nebu je rečeno: 'Jer se nije smilovao, bit će na mukama.' Djelom su otišle: Jednoga dana čistila je Rabijeva služavka kuću i tjerala miševe. Rekao joj je: 'Pusti ih!' Piše: 'Njegova je milost iznad njegovih djela.' (Ps 145). Na nebu je rečeno: 'Jer se smilovao, smilovat ćemo se nad njim.' ${ }^{31}$

Nevjerojatno je da je tako veliki rabin kakav je bio rabin Jehuda Hanasi kažnjen tolikom boli. Čini se da nas Talmud želi poučiti da cijena koju je platio rabi Jehuda Hanasi da bi dostigao potreban uvid $u$ ispravno ponašanje prema životinjama kao Božjim stvorovima, služila kao primjer poruke koju su naši mudraci željeli prenijeti da je klanje dopušteno ako za to postoji ljudska potreba, ali da se usprkos tome ne smije biti indiferentan prema oduzimanju životinjskog života.

Do ovoga smo trenutka položili temelje židovskom pristupu vezanom uz odnos prema životinjama. Židovi moraju njegovati sućut kao osobinu ličnosti te u svakom slučaju izbjegavati okrutnost. Okrutnost, kojom se životinjama uzrokuje patnja, najstrože je zabranjena, dok se osjetljivost potiče.

\section{Vegetarijanstvo i mesna prehrana}

Kada je svijet stvoren, ljudi nisu smjeli jesti meso, nego samo biljnu hranu: »(...) dajem vam sve bilje što se sjemeni (...) neka vam bude za hranu« (Post 1 , 29). Čovjek i sve životinje trebali su biti vegetarijanci. ${ }^{32}$ Mnogo kasnije, nakon deset naraštaja, nakon velikoga potopa, kada su Noa i njegovi sinovi izašli iz korablje, bilo im je dopušteno jesti meso:

\footnotetext{
${ }^{29}$ Jehuda Hanasi, rabi (Bet Šearim, 120. - Izrael, 220.), - pripadnik posljednjeg naraštaja tanaita, izraelski nasi (knez) 140.-200. godine. Nazivan je ukratko Rabi (moj učitelj) ili Rabenu hakadoš (naš sveti učitelj). Bio je sin i nasljednik rabina Šimona ben Gamliela II., sedmi naraštaj od Hilela Starog, koji je potjecao od kralja Davida. Kao sposoban vođa, postigao je dobre odnose između Rimljana i židovske vlasti, a time i slobodu stvaranja za židovske učenjake, te su odnosi Rimljana i židovskog stanovništva bili bolji nego ikada od rušenja drugoga Hrama. Bio je blizak s carem. Svojim osobitim sposobnostima vođenja, nakon neuspjeha ustanka bar Kohve, uspio je uspraviti narod, kako u materijalnom smislu, ojačavajući židovsko vlasništvo nad zemljom u Izraelu i poreznim olakšicama, tako i u duhovnom smislu. Poticao je duhovno stvaralaštvo židovskih učenjaka vlastitom teškom zadaćom: zapisivanjem i uređivanjem usmene Tore Mišne, prvog i najvažnijeg književno-halahičkog djela nakon Biblije. Većinu života proveo je u Bet Šearimu u Galileji, pred kraj života boravio u Ciporiju. O njemu je rečeno: Tora i veličina (bogatstvo i slava) na jednome mjestu. (BT Gitin 59a), te: Otkad je umro Rabi, nema (takve) skrušenosti i straha pred grijehom. BT Sota 49b (Vilne); BT Ketubot 103b (Vilne).

${ }^{30}$ Trinaest je godina patio od zubobolje i bubrežnih kamenaca. Vidi: Jeruzalemski Talmud Teraktat Kilaim, pogl. 9, str. 32b; Midraš Berešit Raba 33: 3, Jeruzalem (reprint izdanja iz Vilniusa, 1878.); Jalkut Šimoni Psalam, 888, Jeruzalem, 1960. (reprint varšavskog izd. iz 1878.).

${ }^{31}$ BT Bava mecia 85a (Vilne); s aram. prev. autori članka.

${ }^{32}$ BT Sanhedrin 59b (Vilne).
} 
»Strah i jeza pred vama uhvatit će svaku životinju na zemlji i svaku pticu na nebu i sve što plazi po zemlji i svu ribu u moru, dani su u vaše ruke. Sve živo što se kreće bit će vam jelo, kao i zelenje, dao sam vam sve« (Post 9, 2-3).

Iako je već u Noino doba postojala podjela na čiste i nečiste životinje, ${ }^{33}$ od tada im je bilo dopušteno jesti svako meso, uz jedno ograničenje: »Ali meso s dušom njegovom, krvlju, ne jedite« (Post 9, 4). Rabin Josef Albo ${ }^{34}$ objašnjava da je dopuštenje konzumacije mesa bilo dovoljno da bi se zadovoljila ljudska žudnja. ${ }^{35}$ Njegov osobni stav o konzumaciji mesa je vrlo negativan: »Osim što je ubijanje životinja okrutno, nepotrebno prolijevanje krvi pomaže razvoju loše naravi; uz to, konzumacija mesa uzrokuje debljanje i neosjetljivost duše čovjekove. « ${ }^{36}$ Slično u svojem komentaru i Don Isaac Abarbanel ${ }^{37}$ objašnjava zašto je Bog dao Izraelcima u pustinji »kruh«, tj. manu, a ne meso:

»Bog je rekao Mojsiju: Meso nije nužna hrana i svrha te hrane je zadovoljenje čovječje žudnje za prejedanjem i jedenjem iz strasti. Osim toga, od mesa osoba postaje okrutna pa su stoga i životinje i ptice grabljivice koje jedu meso okrutne i zle. Ali, ovce i stoka, grlice i golubovi koji jedu samo travu s polja, u sebi nemaju ni okrutnosti ni zla. Stoga je i prorok obećao da će u vrijeme budućeg iskupljenja 'lav jesti slamu k'o govedo' (Iz 11, 7). Tako će biti jer, 'zlo se više neće činiti' (Iz 11, 9). Stoga ni Presveti, neka bude blagoslovljen, nije rekao Mojsiju da će Izraelu dati mesa nego kruha, koji je ispravna i nužna hrana za ljudsku narav. To je značenje stiha: 'Učinit ću da vam daždi kruh s neba.'« ${ }^{38}$

Rabin Abraham Isaac Hahoken Kook, ${ }^{39}$ koji je i sam bio vegetarijanac, na mnogim mjestima govori o pitanju ispravnog odnosa prema životinjam. Iznosi

\footnotetext{
${ }^{33}$ Vidi: Post 7, 2.

${ }^{34}$ Albo, rabi Josef (1380-1444), jedan od kasnijih sefardskih filozofa, s kojima završava doba klasične hebrejske filozofije. Rabin, liječnik i filozof, služio je kao rabin u gradu Daroca u Aragoniji i u gradu Soria u Kastiliji. Njegova jedina knjiga, Haikarim (Načela), koju je napisao na hebrejskome, a koja govori o načelima židovske misli, bila je među prvim tiskanim hebrejskim tekstovima (Soncino, 1485.). Doživjela je više od sedamnaest izdanja, dva važna rabinska komentara (u 16. i 17. stoljeću), te kritičko izdanje uz engleski prijevod (Issac Husik, Philadelphia, 1929-1930).

${ }^{35}$ ALBO Josef, Sefer Ha-Ekarim (Philadelphia, 1929-1930) III, 15.

${ }^{36}$ Isto; s heb. prev. autori članka.

${ }^{37}$ Abarbanel, don Isaac (hebr.: harav Jichak A.) (Lisabon, 1437. - Venecija, 1509.) - Komentator, filozof i političar, potomak kralja Davida, vođa španjolskog židovstva. Portugalski ministar financija u doba kralja Alfonsa V., kao prebjeg iz Španjolske, gdje je također bio rizničar kralja Ferdinanda i njegove žene Izabele (1487.). Za života u Španjolskoj napisao je komentar knjige o Jošui, Sucima i Samuelu. Osam godina služio je kraljevstvu i obogatio Španjolsku, a kada su Židovi 1492. prognani iz Španjolske, on ih je predvodio. Nastanio se u Napulju, gdje je sastavio komentar Knjige o kraljevima i ostalih biblijskih knjiga. Komentirao je i mišnajski traktat Avot (Izreke otaca) i Hagadu za Pesah, a napisao je i filozofske knjige prema Rambamovoj metodi i na temelju njegovih tekstova. U komentaru Tore analizirao je razne društvene sustave svoga doba u usporedbi s društvenim životom Izraela biblijskoga doba.

${ }^{38}$ Abarbanelov komentar Biblije (Varšava, 1862.), Izl 16, 4; s heb. prev. autori članka.

${ }^{39}$ Kook, Abraham Isaac Hakohen (Latvija, 1865. - Jeruzalem, 1935.) - velikan židovske misli posljednjih naraštaja; rabin Jeruzalema, zatim, nakon osnutka Vrhovnoga rabinata, glavni aškenaski rabin Izraela od 1921. do smrti. Duhovni vođa religioznog cionizma. Godine 1888.
} 
i mišljenje naših mudraca koje pronalazimo u Talmudu ${ }^{40}$ da je konzumacija mesa Adamu bila zabranjena i da je čovjeku dopušteno ubijati životinje i jesti njihovo meso samo zato što se čovječanstvo poslije grijeha potopa moralno srozalo. ${ }^{41}$ Ipak, jasno kaže da je konzumacija mesa nemoralna. ${ }^{42}$

Rabin Kook također prepoznaje i negativan stav Tore prema konzumaciji mesa i to u načinu na koji Tora opisuje želju za konzumacijom mesa: »Kad Gospod, Bog tvoj, proširi tvoje područje, kako ti se obrekao, i ti rekneš: 'Jeo bih mesa', jer se duša tvoja zaželjela jesti mesa, jedi mesa koliko ti duša želi« (Pnz 12, 20). ${ }^{43}$ Uporaba riječi "תאווה" (čežnja, strast, požuda) u Bibliji se koristi za označavanje materijalističkih sklonosti. ${ }^{44}$ Rabin Kook objašnjava zašto Tora nije zabranila konzumaciju mesa. Prema njegovom mišljenju, moralni razvoj čovječanstva mora biti postupan. Prvo ljudska bića moraju riješiti problem neprijateljstva i ratova među sobom, a tek će onda moći dosegnuti visoku moralnu razinu etike i pravednog odnosa prema životinjama.$^{45}$ Drugim riječima, dopuštenje konzumacije mesa tek je privremeni moralni ustupak. ${ }^{46}$ Ipak, u već postojeći sustav zapovijedi Tore neprekidno prodiru vrijednosti koje služe kao moralna priprava za promjenu ponašanja ljudske rase prema životinjama u nekom budućem vremenu. ${ }^{47} \mathrm{Na}$ primjer, zapovijed prekrivanja krvi nakon klanja želi podsjetiti ljude da je riječ o moralnom nedostatku i da se moramo stidjeti što smo životinji oduzeli život. ${ }^{48}$ Rabin Kook vjeruje da se u budućnosti u Hramu neće prinositi životinjske nego samo biljne žrtve. ${ }^{49}$

Jamačno je mišljenje rabina Kooka u skladu s općenitim biblijskim stavom prema početku i kraju svijeta, stvaranju i danima Mesije. U rajskome vrtu sva

imenovan je rabinom u Zaumelu, 1895. u Bausku u Latviji; 1904. uselio je u Izrael. Kao rabin Jafoa zapravo je rabin židovskog pučanstva u Izraelu. Pred Prvi svjetski rat nazočio je rabinskome skupu u Europi i bio primoran ostati u Švicarskoj i Londonu do kraja rata, a 1919. vratio se u Izrael. Osnovao je ješivu Merkaz Harav u Jeruzalemu, na čijem čelu je nakon njegove smrti stajao njegov sin, rabin Cevi Jehuda (1890-1983). Ta je ješiva do danas veliko središte proučavanja Tore, a svojim osobitim načinom poučavanja naglašava ljubav za izraelski narod i zemlju. Ostavio je iza sebe riznicu rukopisa s područja kabale, filozofije, halahe, komentara Talmuda, responsa i liturgije, koji do danas još nisu svi objavljeni. Najpoznatija knjiga responsa je »Ezrat kohen « (Pomoć kohena). Mnogo je utjecao na povijest novoga naseljavanja u Izraelu. Njegova osobitost bila je ljubav prema prvim naseljenicima, podjednako vjernicima i nevjernicima.

${ }^{40}$ BT Sanhedrin 59b (Steinsaltz).

${ }^{41}$ Rabin David COHEN, Hazon Hacimhonot vehašalom mibhina Toranit (dalje: Hazon Hacimhonot), Merkaz Harav izd., Jeruzalem, 1961, 49.

${ }^{42}$ Isto, 7-8.

${ }^{43}$ Poslužio sam se prijevodom Varaždinske Biblije, koja je najsličnija izvorniku na hebrejskom jeziku.

${ }_{44}^{44}$ Vidi: Post 3, 6; Br 11, 4; Pnz 12, 20; Sam 1 2, 16; Ps 106, 14; Izr 13, 12.

${ }^{45}$ Hazon Hacimhonot, 14.

${ }^{46}$ Isto, 18.

${ }^{47}$ Isto, 23.

${ }^{48}$ Isto, 23-24.

${ }^{49}$ Vidi: David SPERBER, Korbanot Leatid Lavo beMišnat HaRav Kook, u: Reajot HaRaaja Masot u Mehkarim Betorato šel Harav Kook Zacal, Jeruzalem, 1992, 97-112. 
su Božja stvorenja živjela u slozi i uistinu su bili vegetarijanci. Čitajući proročanstva Izaije, koja opisuju svijet nakon dolaska Mesije, uviđa se to isto:

»Isklijat će mladica iz panja Jišajeva, izdanak će izbit' iz njegova korijena... Vuk će prebivati s jagnjetom, ris ležati s kozlićem, tele i lavić zajedno će pásti, a djetešce njih će vodit'. Krava i medvjedica zajedno će pásti, a mladunčad njihova skupa će ležati, lav će jesti slamu k’o govedo. Nad rupom gujinom igrat će se dojenče, sisanče će ruku zavlačiti u leglo zmijinje. Zlo se više neće činiti, neće se pustošiti na svoj svetoj gori mojoj« (Iz 11, 1.6-9a).

Prorokov opis mesijanskih dana opis je idealnog vremena mira i jedinstva svega što postoji na svijetu. Iako Majmonid slijedi talmudsko mišljenja da taj pastoralni opis ne opisuje buduću stvarnost, već da je samo alegorija, ${ }^{50} \mathrm{u}$ Talmudu postoji i drugo mišljenje prema kojem je ovo opis stvarnoga svijeta. ${ }^{51}$ Stoga možemo reći da će se svijet na kraju vremena vratiti svojim počecima, danima u rajskome vrtu, prije pojave grijeha.

\section{Slučajevi kada je dopušteno povrijediti životinju}

Stav je židovskog zakona da, kada u pitanje dođu razne vrijednosti i interesi, ljudske potrebe imaju prednost te se čovjek ima pravo brinuti za zadovoljenje vlastitih potreba. Stoga je u tim slučajevima dopušteno povrijediti životinju. Postoje dva pristupa vezana uz pravo korištenja životinja za zadovoljenje ljudskih potreba: kada je riječ o dopuštenju da se povrijedi životinja jedan je stav liberalniji, a drugi konzervativniji. Također postoje i dva čimbenika koji snažno utječu na donošenje halahičkih mišljenja: normativna hijerarhija zabrane (je li riječ o biblijskoj ili rabinskoj zabrani) te važnost ljudske potrebe. U nastavku se navode neke potrebe koje židovski zakon prepoznaje i dopušta suspenziju zabrane okrutnosti prema životinjama: potreba za hranom, sprečavanje nanoše-

\footnotetext{
${ }^{50}$ MT hilhot Melahim 12,1; Prema Majmonidu, ovca predstavlja židovski narod koji će u mesijanskim danima moći uživati u miru i slijediti Toru neprogonjen vukovima. Vukovi predstavljaju zločince među narodima svijeta koji su na razne načine progonili židovski narod tijekom cijele povijesti. Majmonid, slijedeći svoju teoriju, objašnjava da sva rabinska žudnja za mesijanskim danima nastaje iz njihove želje za potpunim predavanjem proučavanju Tore. Ovako on piše: »Učenjaci i proroci nisu žudjeli za mesijanskim danima da bi vladali svijetom... niti da bi ih narodi uzdizali, niti da bi jeli, pili i veselili se, već da bi bili oslobođeni za Toru i mudrost i da ih se ne bi ugnjetavalo i ometalo, da bi zaslužili život na svijetu koji će doći« (MT hilhot Melahim 12,4), s heb. prev. autori članka. Ipak će, prema Majmonidovom mišljenju, biti i nekih promjena u prirodi. One će, smatra on, podići duhovnu razinu svijeta: »U to doba neće biti gladi niti rata, ni zavisti niti natjecanja, jer će dobra biti u izobilju i svega ugodnog će biti kao praha, a svijet neće imati činiti drugo do spoznavati Vječnoga. Stoga će Židovi biti veliki učenjaci, znat će tajne stvari i postići će spoznaju svoga Stvoritelja. Kolika je čovjekova snaga, razvidno je iz rečenoga: 'Jer zemlja će se napuniti spoznajom Vječnoga, kao što voda ispunjava more $^{\prime}$ (Iz 11, 9)« (MT hilhot Melahim 12,5; s heb. prev. autori članka).

${ }^{51}$ BT Berahot 34b (Steinsaltz), Šabat 63a (Steinsaltz), Pesahim 68a (Steinsaltz), Sanhedrin 91b (Steinsaltz).
} 
nja zla javnosti, medicinske potrebe, kontrola štetočina i smanjenje prevelikog broja životinja.

Usprkos dopuštenju nanošenja boli životinjama u specifičnim slučajevima navedenih potreba, obvezno je patnju životinje svesti na najmanju moguću mjeru i to tako da se, primjerice, životinju anestezira u slučaju medicinske potrebe. ${ }^{52}$ Kada je riječ o prorjeđivanju broja nekih životinja, postoje rabini koji se tome protive ako su posrijedi čisto ekonomski razlozi. Prema njihovu mišljenju, prorjeđivanje je dopustivo samo radi održanja ekološke ravnoteže..$^{53}$

Rema $^{54}$ dodatno ograničava dopuštenje da se životinji uzrokuje patnja radi raznih ljudskih potreba te kaže da nikakva djela na životinji ne smiju biti okrutna. ${ }^{55}$ Rabi Moshe Feinstein ${ }^{56} \mathrm{u}$ jednoj svoj responsi ${ }^{57}$ postavio je važno pravilo za ovo pitanje. U responsi je raspravljao i, konačno, zabranio nasilno hranjenje, »šopanje« teladi. ${ }^{58}$ Presudio je da svatko tko to čini, krši zabranu okrutnosti prema životinjama jer, iako je u principu dopušteno povrijediti životinju radi ljudskog dobra, taj čin ipak mora biti uobičajen i prihvaćen od strane drugih. Ovaj halahički princip od velike je važnosti jer od osobe zahtijeva ponašanje prema etičkoj normi koju prihvaća i okolina.

Da zaključimo - iako židovski zakon prepoznaje vrijednost ispravnog ponašanja prema životinjama i zabranjuje okrutnost prema njima, židovska tradicija i dalje smatra da je čovjek kruna stvaranja te da je cijeli svemir, uključujući i životinje, načinjen da bi mu pomogao životu i u obavljanju posla. To vidimo i iz nekoliko biblijskih stihova:

»I blagoslovi ih Bog i reče im: 'Plodite se i množite, i napunite zemlju, i sebi je podložite! Vladajte ribama u moru i pticama u zraku i svim živim stvorovima što puze po zemlji!' (Post 1, 28). Neka vas se boje i od vas strahuju sve životinje

\footnotetext{
${ }^{52}$ Rabin Eliezer WALDENBERG, Responsa Tzitz Eliezer, XIV, 74, Jeruzalem, 1996.

${ }^{53}$ Rabin Shlomo ROSENFELD, Hašmadat Odfe Baale Haim, Alon Švut, Thumin 1989, X, 258.

${ }^{54}$ Rema - ISSERLES, Moses (rabi Moše Iserles, skraćeno: Rema) (Krakow, 1520. - Krakow, 1572.) Sin Israela. Vodeći europski aškenaski halahički autoritet svojega vremena. Bio je rabin, glavni sudac i predstojnik ješive u Krakowu, te je utjecao na Njemačku, Poljsku i sjevernu Italiju. Autor je nekoliko knjiga, među kojima je najpoznatija Mapa, dodatak Šulhan Aruhu rabi Josefa Karoa, koja uključuje i aškenaske običaje, te su se obje zajednice mogle služiti jednom zajedničkom knjigom. Pisao je mnogo responsa, poznavao je kabalu, filozofiju, astronomiju, povijest, a osobito Toru i halahu. Već u mladosti imenovan je sucem i predsjedateljem ješive u Krakowu, a za njega je rečeno: »Od Mošea (Majmonida) do Mošea (Rema) nije bilo nikoga kakav je Moše (Rema).«

${ }^{55}$ ŠA Even HaEzer, 5, 14.

${ }^{56}$ Rabi Moše Feinstein (1895-1986) bio je vodeći halahički autoritet, poznat diljem svijeta zbog svojeg poznavanja detalja židovskog zakona, svoje nježnosti i sućuti te su ga mnogi smatrali de facto vrhunskim halahičkim znalcem religioznih Židova u sjevernoj Americi. Njegove halahičke presude često se navode u suvremenoj rabinskoj literaturi.

${ }^{57}$ Responsa - odgovori, u hebr. izvorniku: pitanja i odgovori - šeelot utešuvot, kratica: šut; književnost razmjene pitanja i odgovora, prije svega o halahi, između rabina i sudova u cijeloj dijaspori, od doba gaona do danas (v. još o responsa u DaDon, Židovstvo..., 540-542).

${ }^{58}$ Rabi Moše FEINSTEIN, Responsa Igrot Moše, I Even HaEzer 4, 92.
} 
na zemlji, sve ptice u zraku, sve što se po zemlji kreće i sve ribe u moru: u vaše su ruke predane« (Post 9, 2).

Stoga je općenit stav, prema izvorima židovskoga prava, da zabrana okrutnosti prema životinjama nije apsolutna i da je u nekim slučajevima moguće suspendirati ovu zabranu ako je u suprotnosti s ljudskim potrebama. Vjerujem da se isto može naučiti iz samoga čina stvaranja. Bog je stvorio čovjeka posljednjeg, kao svrhu i krunu stvaranja.

\section{Opasne životinje}

Postoje životinje koje mogu ugroziti ljudsko zdravlje ili dobrobit ili uzrokovati štetu imovini ili okolišu. U takvim slučajevima židovski zakon dopušta ili ponekad čak i zahtijeva ubijanje štetne životinje. Cilj je ukloniti opasnost od javnosti. Iz sljedećeg teksta bit će jasno pripada li i opasan pas ovoj kategoriji. Najistaknutiji slučaj obveze ubijanja opasne životinje je svakako slučaj vola ili neke druge životinje koja je usmrtila čovjeka. ${ }^{59}$ Važno je istaknuti da je pravni postupak za izvršenje kazne nad volom jednak kao i u slučaju osobe optužene za umorstvo. U takvom slučaju, provodi se postupak pred sudom od dvadeset trojice rabinasudaca. Izvor tog zakona pronalazimo u sljedećim biblijskim stihovima:

»Kad goveče ubode čovjeka ili ženu pa ih usmrti, neka se kamenjem kamenuje. Njegovo se meso tada ne smije pojesti, a vlasniku njegovu neka je oprošteno. Ali ako je to goveče i prije bolo, a njegov vlasnik, iako opominjan, nije ga čuvao, pa ono usmrti čovjeka ili ženu, neka se to goveče kamenuje; ${ }^{60}$ a i njegov se vlasnik ima pogubiti« (Izl 21, 28-29). ${ }^{61}$

\section{Obveza vlasnika da izbjegava posjedovanje opasne životinje}

Postoje životinje koje se zbog svoje naravi smatraju opasnima, kako je pisano u Mišni: »Vuk, lav, medvjed, leopard, pantera i zmija smatraju se dokazano opasnima. « ${ }^{62}$ Ovo su životinje koje se najčešće mogu pronaći u zoološkom vrtu i nemaju vlasnike koji bi za njih bili odgovorni. Vlasnik opasne životinje dužan je snositi troškove koje prouzroči njegova životinja. Kada govorimo o opasnim životinjama na mjestima na kojima žive ljudi, najpopularnija životinja je vje-

\footnotetext{
${ }^{59}$ Vidi MT nizke mamon 10, 1-2.

${ }^{60}$ Prva mišna u traktatu Sanhedrin poučava nas da se vola pogubljuje tek nakon što je takvu odluku donijelo sudsko vijeće dvadeset i trojice sudaca.

${ }^{61}$ Vidi Raši, koji objašnjava da se to odnosi na nebesku kaznu koja se može ukinuti plaćanjem, spomenutim u idućim stihovima.; vidi i BT Sanhedrin 15a. (Steinsaltz); MT hilhot Sanhedrin $5,2$.

${ }^{62}$ Mišna Baba Kama 1, 4. Mišna. With Commentary by Pinhas Kehati, Jeruzalem, Eliner Library, Dept. for Torah Education and Culture in the Diaspora of the World Zionist Education, 1987.; s heb. prev. autori članka.
} 
rojatno pas. Židovski zakon izrijekom kaže da je zabranjeno uzgajati opasnog psa. ${ }^{63}$ Zabrana potječe iz ovoga retka: »Svoju kuću nećeš okaljati krvlju« (Pnz $22,8) .{ }^{64}$ To znači da svaka osoba ima obvezu izbjegavati opasnost, čak i kada je riječ o privatnom vlasništvu. Ova zabrana nalazi se i u kodeksu židovskog zakona Šulhan Aruh te kaže da je zabranjeno uzgajati opasnog psa, osim u slučaju kada je čvrsto vezan. ${ }^{65}$ Ako se vlasnik ne brine za psa kako bi trebao i ako opasan pas luta slobodno javnim prostorom te može ozlijediti susjeda ili nekog drugog, Talmud navodi raspravu o tome smije li se takvu životinju jednostavno ubiti, kao oblik samoobrane, ili ne smije. ${ }^{66}$ Majmonid je presudio da je odluka o tome smije li se takva životinja ubiti ili ne u rukama suda. ${ }^{67}$ Nažalost, od vremena do vremena dopiru vijesti o tragičnim slučajevima napada pasa na djecu te je naša trenutna reakcija traženje prikladne kazne za vlasnika psa koji je bio nemaran, ali ne i za samoga psa.

Važno je naglasiti da, ozlijedimo li životinju, možemo i vlasniku nanijeti ozbiljnu povredu. Osobito to vrijedi u slučajevima kada je riječ o psu ili nekom kućnom ljubimcu. U takvom slučaju već zalazimo u prostor zabrane nanošenja boli prijatelju. ${ }^{68}$ Strogo je zabranjeno nanijeti bol prijatelju, makar samo ružno govoreći o njemu, a kamoli ubiti mu kućnog ljubimca. ${ }^{69}$ Treba naglasiti da se navedeno odnosi na situaciju kada ne postoji neposredna i stvarna opasnost od opasne životinje. No, kada je riječ o stvarnoj i neposrednoj opasnosti, jasno je da se napadnuta osoba mora braniti te u samoobrani čak i ubiti psa.

\section{Lov}

Prema židovskom zakonu dopušteno je ubiti životinju samo u specifičnim slučajevima velike potrebe - kao što je konzumacija mesa i to klanjem prema točno određenim pravilima. Ipak, iako je dopušteno ubiti životinju za dobrobit i preživljavanje čovjeka, takav postupak mudraci nisu držali ispravnim nego su ga smatrali moralno problematičnim. Lov su židovska religija i kultura smatrale nečime što pripada Ezavovoj kulturi, o čemu svjedoči i sama Tora: »Ezav postane vješt lovac, čovjek pustare. Jakov je bio čovjek krotak i boravio je u šatorima« (Post 25, 27).

Pitanje lova pojavljuje se $\mathrm{u}$ različitim izvorima rabinske literature, ali se ovdje valja usredotočiti na nekoliko responsi koje potječu iz 17. i 18. stoljeća. Svi

\footnotetext{
${ }^{63}$ Vidi: MT, hilhot Talmud Torah, 6, 14.

${ }^{64}$ Autor stih nije preveo riječima koje se pojavljuju u izvornom tekstu na hebrejskom jeziku (KS - »ne okaljaš krvlju«); vidi još u MT, hilhot Roceah vešmirat hanefeš 11.

${ }^{65}$ ŠA Hošhen Mišpat, 409, 3.

${ }^{66}$ BT, Sanhedrin 15b (Steinsaltz).

${ }^{67}$ MT hilhot Sanhedrin 5, 1.

${ }^{68}$ BT, Baba Mecia 61b (Vilne).

${ }^{69}$ ŠA Hošen Mišpat 248, 4.
} 
rabinski autoriteti zabranjuju lov iz različitih razloga, ali jednako se tako svi slažu da je iznimna okrutnost lova razlog ove zabrane. Prva responsa datira iz 17. stoljeća i njezin autor je Rabin Saul Levi Morteira iz Amsterdama: ${ }^{70}$

»er, loviti znači nalikovati tiranskim kraljevima koji navode životinje u stupicu i ubijaju ih, bez milosti šaljući na njih pse da bi ih rastrgnuli. Stoga je lov zabranjen u našoj Tori jer on navodi na okrutnost te je zato upozorenje protiv te prakse tako ozbiljno. Radi toga je i Bog zapovijedio da pokrijemo krv životinje poslije klanja jer nalikuje prolijevanju čiste krvi koja se mora prekriti.« ${ }^{71}$

Iduće response potječu iz 18. stoljeća, napisao ih je rabin Šabetaj Milojkjo (17. i 18. stoljeće, Italija) kao odgovor na ovo pitanje:

»Ljudi love rukama ili pticama za lov i raznim ručnim oruđem, ako je lov rukama zabranjen, a ako je dopušteno trgovati ulovljenim životinjama. Ako ljudi love radi zabave i sporta, odnosi li se zabrana i na njih? «" ${ }^{72}$

Rabin Šabetaj Milojkjo ovako odgovara:

»Razmisli sâm, ako čovjek zamoli svojeg prijatelja da ga istuče kao oblik šale, neće li biti kažnjen? Zasigurno hoće! Kakva je razlika između ljudi i životinja? Ovdje [o životinjama] ovako piše: 'Njegova je milost iznad njegovih djela' (Ps 145). I, iako ih je dopušteno klati, nije ih dopušteno ubijati vlastitim rukama [lovom]. « $^{73}$

Rabin Šabetaj Milojkjo dodaje i da lov zabranjuju kako židovski zakon, tako i židovski običaj. Iduću responsu napisao je rabin Samson Morpurgo ${ }^{74}$ iz Ancone:

»Zbog shvaćanja zlog ponašanja Ezava i opasnosti prihvaćanja okrutne naravi koja dopušta ubijanje stvorova Presvetog, Blagoslovljenog, bez ikakvog razloga i zbog beskorisnog provođenja vremena u 'zboru podrugljivaca' (Ps 1, 1), jer je rečeno: 'Ne smije se odlaziti na stadione' (BT Avodah Zarah 18b)... U svakom slučaju, čini mi se da, čak i ako ne postoji zabrana u Tori [odlaska u lov], svejedno

${ }^{70}$ Rabin Saul Levi Morteira (1596-1660) bio je nizozemski rabin te rabin sefardsko-portugalske zajednice u Amsterdamu. Jedan od njegovih slavnih učenika bio je i Baruch Spinoza.

${ }^{71}$ Rabbi Saul Levi MORTEIRA Givat Šaul, Parašat Vaješev, Varšava, 1915, 44a; s heb. prev. autori članka.

${ }^{72}$ Vidi: Yitzhak LAMPARONTI, Pahad Yitzhak, sv. 10, Lyck, 1874, 18-21; Pitanje i odgovor pronalazimo kod rabina Isaaca Lamprontija (1679-1756), talijanskog rabina i liječnika koji je služio kao rabin Ferrare i slavan je zahvaljujući rabinskoj enciklopediji Pahad Yitzhak; s heb. prev. autori članka.

${ }^{73}$ Isto, s heb. prev. autori članka.

${ }^{74}$ Rabin Samson Morpurgo ben Joshua Moše (1681-1740) bio je bosansko-talijanski rabin, liječnik i liturgičar. Morpurgo je rođen u Gradiški u Bosni. Kao sedmogodišnjeg dječaka otac ga je odveo u Veneciju da izuči Toru. Nakon toga je studirao na sveučilištu u Padovi i stekao diplomu liječnika. Istovremeno se posvetio proučavanju Talmuda i rabinskih spisa te je godine 1709. primio i rabinsku diplomu iz ruku Leona Briela, glavnog rabina Mantove. Nedugo poslije toga postao je suradnik rabinata u Anconi i rabina Josepha Fiamette, a ubrzo i njegov zet. Poslije smrti Fiamette 1721. godine, Morpurgo je izabran za glavnog rabina Ancone, koji je položaj zadržao do svoje smrti, otprilike 20 godina poslije. Morpurgo je ostavio cijeli niz responsa na četiri dijela Šulhan Aruha, koje je s bilješkama i opaskama objavio njegov sin Moše Haim Šabetai (Venecija, 1743.). 
postoji zabrana jer je smrt životinje dopuštena samo radi dobra ljudskog roda, a ne da steknemo narav ispunjenu okrutnošću, prolijevanjem krvi i ubijanjem. $\ll^{75}$

Slijedi responsa rabina iz Praga ${ }^{76}$ Yehezkela Landaua iz 18. stoljeća, poznatijeg kao Noda Bijehuda. Bogati Židov postavio mu je pitanje dopušta li Tora lov iz sporta. Na to mu je Noda Bijehuda odgovorio da je takav postupak sigurno protivan duhu Tore koja Nimroda i Ezava opisuje kao lovce. Noda Bijehuda ističe pet halahičkih problema koji se pojavljuju u slučaju lova kao sporta: nanošenje boli životinjama, destruktivnost, ugrožavanje vlastite osobe, nepostojanje židovskog običaja koji bi svjedočio da su se Židovi ikada bavili lovom, nemoralnost. Donosimo citat iz response Noda Bijehuda:

»Do sada smo govorili s gledišta zakona. Ali, uistinu me sama tema zaprepašćuje. Naziv 'lovac' pronalzimo samo u tekstovima o Nimrodu (Post. 10:9) i o Esavu (Post 25, 27). No, to nije put Abrahama, Izaka i Jakova. (...) I, kako bi Izraelac mogao ubiti životinju motiviran ničim drugim nego provođenjem vremena u lovu? «7 $^{77}$

Lov je, kako kaže Noda Bijehuda, zabranjen i potpuno je u suprotnosti s židovskom etikom. Čovjek mora poduzeti sve što je u njegovoj moći da bi zaštitio život, jer je rečeno: »Pazite dobro!« (Pnz 4, 15) i nije se dopušteno dovoditi u opasnost od drugih zvijeri. Osim toga, Noda Bijehuda dodaje da, iako postoji običaj da se osobi koja ima novi komad odjeće na njemu čestita i poželi da u njemu uživa, isto nije dopušteno učiniti za odjevni predmet načinjen od životinjske kože jer: »Njegova je milost iznad njegovih djela « (Ps 145). ${ }^{78}$

\section{Borba s bikovima}

Pitanje poslano rabinu Ovadiji Josefu ${ }^{79}$ glasilo je: »Je li halahički dopušteno otići na stadion i gledati borbu s bikovima?« U civiliziranoj, modernoj i seku-

\footnotetext{
${ }^{75}$ Rabin Samson MORPURGO, Responsa Šemeš Cdaka, Venecija, 1743, Jore Dea 57; s heb. prev. autori članka.

${ }^{76}$ Rabin Yehezkel Landau iz Praga (1713-1793), bio je utjecajni znalac halahe (židovskog zakona). Najpoznatiji je po svojim Responsama Noda Bijehuda (Poznat u Judeji), imenu po kojem je također ostao zabilježen u povijesti. Godine 1755. postavljen je za glavnog rabina Praga. Landau je bio izuzetno cijenjen, ne samo u zajednici nego i šire te je bio vrlo poštovan u krugovima vlasti. Stoga je bio u poziciji da se zauzme kod vlasti u brojnim slučajevima kad su uvođene antisemitske mjere. Iako se nije protivio sekularnom znanju, protivio se »onoj kulturi koja je stigla iz Berlina «, osobito prijevodu Tore Mosesa Mendelssohna.

${ }^{77}$ Rabin Yehezkel LANDAU, Responsa Noda Bijehuda, Jeruzalem, 1960, Part 2, Yoreh Dei'ah 10; s heb. prev. autori članka.

${ }^{78}$ Vidi: ŠA Orah Haim 223, 6.

${ }^{79}$ Rabin Ovadia Josef (1920-2013), talmudski znanstvenik i stručnjak, rođen u Iraku, sefardski glavni rabin Izraela od 1973. do 1983., te utemeljitelj i dugogodišnji duhovni vođa izraelske sefardske ultra-ortodoksne stranke Shas. Response rabina Josefa imaju veliku važnost u ortodoksnoj zajednici.
} 
larnoj kulturi često se raspravlja o moralnosti borbe s bikovima te o tome treba li je zabraniti, kao što je učinjeno u Barceloni, ili očuvati kao sport ili oblik umjetnosti, kako su učinili u Madridu?

Nemamo nikakvih informacija o osobi koja je poslala pitanje. Ali, možemo pretpostaviti da je pitanje stiglo od Židova koji je svoj godišnji odmor provodio u nekoj europskoj državi poput Španjolske ili u Južnoj Americi, gdje je borba s bikovima još uvijek jako popularna, jer je vjerojatno želio nešto naučiti i iskusiti lokalnu kulturu, ali je istovremeno, kao bogobojazan Židov, želio znati dopušta li halaha ${ }^{80}$ takvo što. Rabin Ovadia iskoristio je svoj odgovor da bi poučio i druge ljudi koji su se možda borili s istim pitanjem te iskoristio problem borbe s bikovima da objasni stav Tore o odnosu prema životinjama. Donosimo prijevod njegova odgovora:

»Nema nikakve sumnje da je sama ideja borbe s bikovima u potpunoj opreci s duhom naše svete Tore. Jer [borba s bikovima] je kultura grešnika i okrutnih ljudi, a ne dar koji je Bog dao Jakovu, kako kažu naši mudraci (BT Yevamot 79a): 'Postoje tri glavne karakterne osobine uobičajene za Židove: Židovi su skromni, sućutni i dobrohotni' ... Dobro je poznato da zabrana okrutnosti prema živim stvorenjima potječe iz Biblije. Upravo zato Tora nalaže uklanjanje tereta s leđa tuđeg magarca, ako je životinja pala pod opterećenjem. Talmud (Bava Mecia 31a-32b) je iz tog stiha zaključio da je zabrana nanošenja patnje životinjama zabrana na biblijskoj razini.

U traktatu Šabat 128b, mudraci Talmuda kažu da, ako je životinja na šabat pala u kanal vode i ako je voda preduboka da bi se životinja nahranila dok je još u kanalu, dopušteno je rasprostrijeti jastuke i pokrivače pod noge životinje kako bi je se podiglo dovoljno da je se može nahraniti. Iako se time krši jedan od zakona šabata time što se 'posuda' čini neupotrebljivom - a to je izvedenica zabrane uništavanja (kako Raši ${ }^{81}$ objašnjava u odjeljku u traktatu Šabat 128, i u 154b, te

${ }^{80}$ Halaha - 1. pravni dio židovske vjerske književnosti; naziv dolazi od glagola »halah « (ići), jer »idemo«, to jest slijedimo židovsko pravo. 2. pojedina odredba iz sustava halahe; vidi još u DaDon, Židovstvo..., 481.

${ }^{81}$ Šelomo Jichaki, rabi, skraćeno: Raši (1040-1105) - Najveći komentator Tanaha, Mišne i Talmuda. Studirao je u ješivama u Troyesu i u području rijeke Reine. U godini 1070. osnovao je ješivu u Troyesu, gdje je imao mnogo studenata. Pri kraju života doživio je strašnu nevolju koju su Židovi iskusili tijekom Prvoga križarskog pohoda, kada je mnogo Židova ubijeno u križarskim nastojanjima da ih se prisilno preobrati na kršćanstvo. Raši nije imao sinova, nego tri kćeri, a sinovi njegove kćeri Johevet su rabenu Šemuel ben Meir i rabenu Jakov »Iš Tam«, nazvan rabenu Tam; obojica su među utemeljiteljima škole Baale hatosafot (Posjednici dodataka), čiji se komentari do danas objavljuju pored Rašijevih komentara. Njegov komentar babilonskog Talmuda nedvojbeno je najznamenitiji komentar Talmuda. Na starofrancuskome ili na njemačkome objašnjavao je teško razumljive aramejske riječi, te u njegovom komentaru ima oko 3.000 nehebrejskih riječi. Bez Rašijevog komentara Talmud danas gotovo ne bi bio razumljiv, jer je genijalno načinjen da ga može rabiti i učenik i učenjak. Komentar je utemeljen na aškenaskoj tradiciji, koju je primio od svojih rabina, uz njegove vlastite dopune. Komentar je pisao osobitim pismom, koje se po njemu naziva Rašijevo pismo, a njime se i danas tiskaju Tanah, Mišna i Talmud. Na taj je komentar napisano gotovo tristo drugih komentara. Upravo taj je tekst bio i prva tiskana hebrejska knjiga, 5235. godine prema židovskome računanju, odnosno 1475. godine, u Reggio di Calabriji u Italiji. Kada se ova knjiga proširila, potisnula 
u Tosafot u Šabat 43a) - mudraci su takav postupak ipak dopustili jer je zabrana da se posuda učini neupotrebljivom samo rabinska zabrana, dok je zabrana nanošenja patnje životinji biblijska. Biblijska zabrana ima veću snagu od rabinske. Tako su prosudili Majmonid, ${ }^{82}$ Tur i Šulhan Aruh. ${ }^{83}$ Ali u ovom slučaju [borbe s bikovima], životinju se izgladnjuje i nanosi joj se bol prije negoli uđe u arenu. Nakon toga, životinju se draži, provocira i bode oružjem da bi podivljala i počela prijetiti rogovima. Naši su rabini, što je potpuna suprotnost ovome, zabranili čovjeku da jede prije negoli je nahranio životinju, kao što objašnjava BT Berachot 40a. Svoju zabranu rabini su temeljili na stihu koji prvo kaže: 'Travu ću davati po tvome polju tvome blagu', a tek zatim: 'Tako ćeš jesti i biti sit' (Pnz 11, 15). Ova halahička presuda pojavljuje se u Šulhan Aruh Orah Haim 167.

U Gemari u Bava Metziji (85a) rabini su ispričali anegdotu o našem Svetom Rabinu [kako se u Talmudu naziva rabin Jehuda Princ], koja kaže da treba biti milostiv čak i prema nečistim glodavcima jer je pisano: 'Njegova je milost iznad njegovih djela' (Ps 145, 9). Priča nas uči da će Nebo biti milostivo prema svakome tko je milostiv prema Božjim stvorovima i da će ga poštedjeti patnje.

Rabin Haim ben Atar, ${ }^{84}$ u svojoj knjizi Or Hahaim (u komentaru na Parša Ahare Mot [Lev 17, 11]), piše da je zabranjeno ubiti ili na neki drugi način usmrtiti bilo koju pripitomljenu ili divlju životinju. Dopušteno nam je klanje isključivo u svrhu konzumacije mesa. Čak i vola koji je izmasakrirao i ubio čovjeka smije se ubiti samo ako je tako odlučio Sinedrij, ${ }^{85}$ sud dvadeset i trojice sudaca.

je sve druge komentare Talmuda. U prvom tiskanom izdanju Talmuda, 1484. u talijanskome Soncinu, uz svaku stranicu je tiskan i ovaj komentar, te je otada temelj proučavanja Talmuda u svjetskome židovstvu. Veliko znanje u mnogim poljima, kao što su hebrejska gramatika, proizvodnja vina, poljodjelstvo, trgovina, proizvodnja tekstila i drugima, bilo je temelj za neponovljivu jednostavnost i jasnoću njegova komentara. Majmonid, koji je djelovao u 12. stoljeću, ostavio je zapis o tome da je jako želio napisati komentar Tore, no odustao je zbog opširnoga Rašijevog komentara, jer, kako je sam rekao, bio bi ga napisao »da me nije preduhitrio Francuz«.

${ }^{82}$ MT Šabat 25:26.

${ }^{83}$ Tur (Vilnius, 1923.) Orah Haim 305:19; ŠA Orah Haim 305:19.

${ }^{84}$ Rabin Haim ben Atar, poznatiji kao Or haHaim prema popularnom komentaru Tore kojeg je sastavio, bio je talmudist i kabalist. Rođen je u Meknesu u Maroku godine 1696., a umro u Jeruzalemu 1743. godine. Bio je jedan od najpoštovanijih rabina u Maroku. Godine 1733. odlučio je napustiti svoju domovinu i odseliti u Izrael, koji je tada bio pod otomanskom vlašću. Na putu su ga u Livornu zadržali bogati članovi židovske zajednice koji su za njega utemeljili ješivu. Mnogi njegovi učenici kasnije su postigli slavu i osigurali mu sredstva za tiskanje knjige Or ha-Haim (Svjetlost života). Godine 1742. stigao je u Jeruzalem gdje je predsjedao ješivom Kenesset Yisrael. Jedan od njegovih učenika bio je i rabin Chaim Joseph David Azulai, slavni Hida. Sahranjen je na židovskom groblju na Maslinskoj gori u Jeruzalemu, u Izraelu.

${ }^{85}$ Sinedrij - Vijeće staraca; izvor riječi je grčki (sunédrion); židovsko legislativno tijelo i vrhovni sud u doba drugoga Hrama, od hašmonejskoga doba (165. pr. Kr.) do 425.; od gubitka neovisnosti 70. godine do kraja svoga djelovanja preuzima od kralja zastupanje zemlje pred rimskim i bizantskim vlastima; sastojao se od 71 člana, što je spomen na Mojsija i 70 staraca. Predsjednik sinedrija bio bi i vođa naraštaja, najmudriji čovjek svoga doba, poput zamjenika na Mojsijevu mjestu u svakome naraštaju. Sinedrij je vodio predmete koji su imali utjecaj na sav židovski narod: imenovanje kralja, imenovanje Maloga Sinedrija (33 suca u svakome gradu i plemenu), zakone o lažnim prorocima, teorijski slučajevi kada bi Veliki svećenik počinio zločin koji se kažnjava smrću, proširivanje granica Jeruzalema, te izlazak u rat kada kada nije bila obveza, i slično. Sinedrij je zasjedao u Hramu dok je postojao, a 40 godina prije rušenja premješten je, te 
Noda Bijehuda (Dio II Yoreh Dei'ah 10), na pitanje je li dopušteno loviti životinje radi sporta i zabave, zaključuje da je to zabranjeno, kako zbog toga što lovac u opasnost dovodi vlastiti život, tako i stoga što takav čin uključuje okrutnost i uzrokuje nanošenje boli životinjama.

Na temelju svega navedenog jasno je da osoba koja uđe na stadion da bi gledala borbu s bikovima i plati ulaznicu 'drug je razbojniku' (parafrazirajući Izr 28, 24). Takav čovjek pomaže i podržava grešnike, što je zabranjeno prema Mišni u Gitinu (61a).

Rabin Shimon ben Pazi ovako objašnjava: 'Blago čovjeku koji ne slijedi savjeta opakih' (Ps 1,1$)$ - to se odnosi na kazališta i cirkuse ne-židova, ‘i ne sjeda u zbor podrugljivaca' (Ps 1,1$)$ - 'ne prati borbe divljih životinja (hebr. kenigyon)'. Raši objašnjava da se riječ »kenigyon « odnosi na lov pasa na divlje životinje, što se činilo isključivo radi zabave i sporta. Jednako tako, ova se riječ pojavljuje u Talmudu, Traktat Hulin $60 a,{ }^{86}$ koji retorički pita: 'Je li Mojsije bio lovac (je li poznavao rijetke životinje)?' U Or Zarua Hagadol (Dio II, Zakoni šabata, 83, 17) autor piše: 'Svatko tko lovi životinje koristeći se psima neće zaslužiti radost Levijatana' [na gozbi pravednika u budućem svijetu], kako objašnjava Midraš Raba (Lev 13, 3)... sačuvaj, Bože, da bi čovjek odlazio na mjesta gdje se igraju okrutne igre s životinjama i stoga razvio loša i pokvarena svojstva okrutnosti; takav će čovjek svoju dušu uništiti vlastitim rukama (Izr 6, 32). To nije baština koja je dana Jakovu. Stoga je jasno da je zapovijeđeno svima objaviti da je zabranjeno odlaziti na takva mjesta. Oni koji poslušaju, bit će sretni i na njih će sići blagoslov dobrote. ${ }^{87}$

Rabin Ovadia nimalo ne sumnja da je takvo što okrutno i da ne pristoji duhu Tore ni židovskoj naravi. Borba s bikovima nije židovski sport. Ne samo da je zabranjeno sudjelovati u borbi s bikovima, to je okrutan grijeh, nego je čak zabranjeno pomagati, podržavati ili olakšavati drugima da tako griješe i to postpcima kao što je kupovina ulaznice za gledanje borbe s bikovima. Osim toga, talmudski izvori opisuju sjedenje na stadionu i promatranje borbe životinja kao »sjedenje u zboru podrugljivaca« (Ps 1, 1). Čak je i gledanje borbe bikova u vlastitom domu pogrešno. Osim toga, možemo nedvojbeno dodati da isto vrijedi za sve vrste borbe životinja: ptica, pasa i drugih. Sve je to zabranjeno iz istoga razloga. Kao ljudska bića stvorena na sliku Božju, moramo njegovati milosrđe i dobrotu. Zlostavljanje životinje je zlostavljanje bespomoćnoga. Kada gledamo publiku koja prati borbu bikova, viče »Ole!« i navija zajapurenog lica i krvavih očiju, gledajući bika kojem iz leđa vire noževi i iz râna mu teče krv, možemo li od tih i takvih ljudi očekivati sućut prema susjedima nakon što izađu iz stadiona? Osoba koja je neosjetljiva prema osjećajima životinje bit će jednako tako neosjetljiva i prema osjećajima drugih ljudi.

se selio kroz deset različitih mjesta, od kojih je posljednje bilo Tiberijas. Tradicijski se smatra da će se u mesijanskome dobu Sinedrij vratiti u Tiberijas, a zatim u Hram.

${ }^{86}$ Objašnjavajući zakone kašruta, Mojsije je poučavao ljude, govoreći o raznovrsnim rijetkim životinjama.

${ }^{87}$ Rabin Ovadia JOSEF, Responsa Jehave Daat, Jeruzalem 1977-1984, III, 66, 206-209; s heb. prev. autori članka. 


\section{Sućut i dobrota prema životinjama i moderna industrija hrane}

Stav koji se može iščitati iz više navedenih izvora židovskog zakona u potpunoj je suprotnosti s načinom na koji se životinje tretiraju u modernoj industriji hrane koja ih smatra sredstvom proizvodnje. Industrija hrane životinje uglavnom iskorištava, ne obraćajući pažnju na njihovu dobrobit. Na primjer, mnoštvo životinja se smješta na vrlo malen prostor da bi se uštedjelo na mjestu i na novcu ili kokoši, koje se izlažu umjetnom svjetlu kako bi se prevarilo njihov biološki sat i dobilo više jaja. U današnjoj, modernoj industriji hrane prema životinjama se ni u kojem slučaju ne odnosimo kao prema pojedincima, »osobama«.

Mogu li ljudi koji nisu vegetarijanci i ne namjeravaju prijeći na vegetarijanski način prehrane doprinijeti promjeni stava industrije prema životinjama? Odgovor je bez sumnje da! A pomoći mogu na dva načina: Prvi način odnosi se na kupovinu proizvoda onih proizvođača koji brinu o dobrobiti životinje. Mogu kupovati proizvode kao što su »jaja iz slobodnog uzgoja« ili »organska jaja umjesto industrijskih jaja. ${ }^{88}$ Drugi način odnosi se na prestanak konzumiranja proizvoda proizvedenih postupcima koji su okrutni prema životinjama, kao na primjer guščja jetra ${ }^{89}$ i bijela teletina od mlijekom hranjene teladi. ${ }^{90}$ Sve su to skupi proizvodi čija proizvodnja životinjama uzrokuje veliku patnju. S jedne strane, cijena organskih jaja malo je viša od cijene industrijskih jaja. Ali, s druge strane, ako se potrošači uzdrže od konzumacije delikatesa kao što su

\footnotetext{
${ }^{88}$ Industrijska kokošja jaja - kokoši u prirodi žive u malim grupama u kojima svaki član zna svoje mjesto i identificira se $\mathrm{s}$ drugim članovima grupe. Kokoši trče i lete, jaja nesu u privatnosti u gnijezdima koja su same svile. Ništa od navedenoga ne postoji u industrijskim kokošinjcima u kojima su životinje zbijene u dugim, uskim kavezima. Kokoši se ne mogu kretati, ne mogu raširiti krila, željezna mreža na kojoj stoje ranjava im noge, a jaja nesu bez ikakve privatnosti. Naguranost i stres navodi kokoši da kljucaju vlastito perje ili perje svojih susjeda. Da bi se to spriječilo, uobičajilo im se rezati kljunove dok su još vrlo mali. To se obavlja uređajem nalik na giljotinu s vrelim oštricama. Postupak uzrokuje pilićima dugu i snažnu bol jer se u kljunu nalaze i živci.

${ }^{89}$ „Šopanje« gusaka zabranjeno je u SAD-u i u nekim europskim državama. Guske se drže u kavezima tako da se ne mogu pomaknuti i potrošiti energiju, s ciljem da hrana koja prisilno uđe u njihova tijela uzrokuje pretilost. Guske se šopa kroz čvrstu cijev kojom se u njihova tijela uvode ogromne količine hrane, a rezultat je i do deset puta uvećana jetra. Guska ima ozbiljne zdravstvene probleme koji uključuju rupture ezofagusa uzrokovane guranjem cijevi, probleme s disanjem, nekrozu jetre i unutrašnja krvarenja. Uvećana oboljela jetra pritišće unutrašnje organe tako da je guski teško doći čak i do bazena s vodom. Stanovit postotak gusaka ugine tijekom procesa šopanja.

${ }^{90}$ Meso mlijekom hranjene teladi - riječ je o telićima koji su gotovo u vrijeme teljenja oduzeti majkama i namjerno uzgajani tako da budu bolesni. Kako bi telići ostali meki i blijedi, hrani ih se tekućom zamjenon za mlijeko u kojoj nema željeza i vlakana te zbog toga životinje postaju anemične. Telići život provode zaključani u malim, mračnim ćelijama u kojima se ne mogu okrenuti da ne bi jačali mišiće te da bi im meso bilo meko. Kolje ih se u dobi od otprillike četiri mjeseca.
} 
guščja jetra i teletina mlijekom hranjene teladi, koje su osobito skupe, bez sumnje će uštedjeti mnogo novca. Ipak, važniji razlog uzdržavanja od konzumacije proizvoda čija je proizvodnja uzrokovala životinjsku patnju jest to što čovjek tako svojem ponašanju pridodaje praktičnu dimenziju i definira svome stavu o okrutnosti spram životinja.

\section{Zoološki vrt}

Sagledajmo i stav židovstva prema posjetu zoološkom vrtu te o tome je li to korisno provedeno vrijeme. U prije navedenom odgovoru rabina Ovadije Josefa pronalazimo odgovor i na to pitanje. Rabin Josef ne samo da dopušta posjećivanje zoološkog vrta, on to i potiče. Posjetom zoološkom vrtu čovjek može produbiti svoju vezu s Bogom gledajući čudo Božjih stvorenja u mirnom i dostojanstvenom okruženju. Mišljenje rabina Ovadije u suprotnosti je sa stavom dvojice halahičkih autoriteta iz 19. stoljeća, koji su zabranjivali posjet zoološkom vrtu. Ovako u svojem odgovoru kaže rabin Ovadija:

»Čini se jasnim da je dopušteno odlaziti u zoološki vrt i promatrati stvorenja koja je oblikovao Presveti, Blagoslovljeni. Ljudska bi duša trebala biti dirnuta pogledom na čudesna djela Božjih ruku, kako je rečeno: 'Kako su brojna tvoja djela, o Gospode! Sve si to mudro učinio: puna je zemlja stvorenja tvojih.' (Ps 104, 24) (...) A u knjizi Leket Yošer, pisac svjedoči o velikom rabinu Israelu Isserleinu, ${ }^{91}$ tvorcu response Terumat Hadešen, te kaže da je rabin Isserlein na šabat prešao značajnu udaljenost da bi vidio par lavova koji su stigli u njegov grad. I naš učitelj Hida, ${ }^{92}$ (...) pripovijeda da, kada je bio u Londonu, posjetio je zoološki vrt i vidio mnoštvo zanimljivih i čudnih životinja, uključujući i orla za kojeg se pričalo da je star sto godina. U knjizi Maagal Tov dodatno pripovijeda o tome. Imamo snažne halahičke dokaze da je dopušteno posjetiti zoološki vrt jer znamo da je to učinio i veliki rabin. Također smo čuli da je mnoštvo velikih i mudrih ljudi, vrlo pobožnih i poznatih po mnoštvu dobrih djela, također posjetilo zoološki vrt i nitko se tome nije protivio. «"93

Ovako pri opisu svog posjeta Kraljevskoj menažeriji u Toweru kaže sam Hida:

»A ja, mlad, vidio sam čudne, zastrašujuće životinje u londonskom Toweru, životinje snažnije od lavova i vezane željeznom užadi. Osim toga, vidio sam predivnog orla za kojeg se priča da je sto godina star, tako čak piše i u njiho-

\footnotetext{
${ }^{91}$ Rabin Israel Isserlin (rođen 1390. u Mariboru, Štajerska - umro 1460. u Bečkom Novom Mjestu, Austrija) bio je talmudist, halahičar najpoznatiji po svojem djelu Terumat HaDešen, koje je služilo kao izvor za HaMapah, djelu Šulhan Aruha kojeg je napisao rabin Moše Isserles.

${ }^{92}$ Azulaj, Hajim Josef David - Hida (Jeruzalem, 1724. - Livorno, 1806.), rabin i kabalist. Kao poslanik, putovao je od zajednice do zajednice, te je bio i rabin u Kairu. Napisao je trideset osam knjiga komentara, kabale i halahe, koje su prihvatili i Sefardi i Aškenazi.

${ }^{93}$ Rabin Ovadia JOSEF, Responsa Jehave Daat, Jehave Daat III, 66, 206-209; s heb. prev. autori članka.
} 
vim knjigama. Vidio sam i mješanca lavice i mačka - izgledao je kao predivna mačka, ali bio snažan kao lav i morao je biti vezan cijelim nizom željezne užadi na mračnom i strašnom mjestu. Osim toga, bilo je tamo i mnoštvo različitih životinja iz Amerike. « ${ }^{94}$

Rabin Ovadia svoj odgovor zaključuje ponavljanjem razlike između poučnog iskustva koje se može steći posjetom zoološkom vrtu te divljenja Božjim djelima i moralno osiromašujućem iskustvu gledanja borbe s bikovima, koje svakako treba izbjegavati. Osobno sam skloniji mišljenju rabina Ovadije jer uistinu osjećam snažno i iskreno divljenje prema Božjem stvaranju svaki put kada posjetim zoološki vrt. Takve posjete zoološkom vrtu ne smatram gubitkom vremena nego pozitivnim tjelesnim i duhovnim iskustvom koje nam daje snagu za nastavak životnoga duhovnog putovanja.

\section{Zaključak}

U halahičkoj literaturi postoji neslaganje je li zabrana okrutnosti prema životinjama rabinska zabrana ili je zabrana koja potječe iz same Tore. Ipak, prema svim mišljenjima, zabranjeno je nanositi životinjama nepotrebnu patnju ili im nanositi patnju u slučajevima kada je potreba koja postoji nevažna, neprilična ili kada se cilj može postići i na druge načine. Što se vegetarijanstva tiče, mnogi rabini protive se konzumaciji mesa i smatraju dopuštenje konzumacije mesa samo privremenim moralnim ustupkom. Različiti židovski izvori, od Biblije do rabinske literature zahtijevaju humano i osjećajno ponašanje prema životinjama te traže osjetljivost prema njihovoj patnji i potrebama. Postoji zabrana nasilja nad životinjama koje može uzrokovati životinjsku patnju ili uzrokovati zlostavljanje životinje.

Ipak, postoje iznimke kada je ova zabrana suspendirana, situacije kada je dopušteno uzrokovati životinjsku patnju, ali na način koji ne uključuje okrutnost prema životinji, te koji je uobičajen i prihvatljiv okolini. Kada se životinja mora ubiti, to treba učiniti tako da se uzrokuje najmanja moguća količina patnje, onako kako se to čini pri ritualnom košer klanju. Lov je zabranjen iz mnoštva razloga te se protivi židovskoj etici i židovskom zakonu. U slučaju kada je opasna životinja opasna za javnost, židovski zakon dopušta obranu od takve životinje i ubijanje životinje koja je usmrtila čovjeka. Također, židovski zakon dopušta ubijanje opasne životinje, iako ona možda još nije ubila čovjeka, ali čini neposrednu opasnost. Ipak, ovu pravnu iznimku treba koristiti što je moguće rjeđe i samo u slučajevima kada se nužno obraniti od opasnosti. U slučaju agresivnog i opasnog psa, čak je i subjektivan strah dovoljan razlog da se dopusti ubijanje takvog psa, ako mu nije moguće pobjeći na neki drugi način. U svakom

\footnotetext{
${ }^{94}$ Rabin Hajim Josef David AZULAJ, Midbar Kedeimot, Jeruzalem, 1957, 2, 22, 25; s heb. prev. autori članka.
} 
slučaju, čovjek mora uzeti u obzir i mogućnost da će vlasnik životinje ubojstvo svoje životinje shvatiti kao osobnu uvredu, kao što je to slučaj s kućnim ljubimcima na koje je vlasnik navikao i uz koje je vezan. Tako uzrokovati bol drugima strogo je zabranjeno. U nekim situacijama, kada su osobna dobra u opasnosti, judaizam dopušta zaštitu privatnog vlasništva, čak i ako se pri tome nanese ozljeda i bol uzročniku opasnosti. No, i u takvim slučajevima treba slijediti pravilo proporcionalnosti.

Generalni stav kojega možemo iščitati iz navedenih izvora u židovskom zakonu u potpunoj je suprotnosti s odnosom moderne industrije hrane prema životinjama, koja ih smatra sredstvima proizvodnje. Ipak, naveli smo i nekoliko prijedloga kojima bi se takva situacija mogla početi mijenjati. I na kraju, židovstvo podržava posjet zoološkom vrtu, u stvari, ono takav čin potiče. Iskustvo je to koje produbljuje vezu čovjeka sa Stvoriteljem. 


\section{Agnes Eva DaDon* - Kotel DaDon* \\ The attitude of Judaism toward animals in the Old Testament, Jewish Law and Rabbinic literature \\ Summary}

The article analyzes the attitude of Judaism toward animals and some key questions such as: vegetarianism and meat consumption, cases when hurting animals is allowed, attitude towards dangerous animals, hunting in Judaism, bullfighting, the way animals are treated by the modern food industry and offers some suggestion about what can be done to remedy the situation. The final part of the article describes the attitude of Judaism toward visiting a Zoo. In the article, the authors first provide an introductory explanation regarding compassion and kindness toward animals in Judaism. In the second part of the article, the authors analyzes the aforementioned topics in the Old Testament, Jewish law and Rabbinic literature from Talmudic times onwards. The authors investigate these questions using sources from Rabbinic literature and responsas, from Talmudic times, through the Middle Ages to the present-day Rabbis. In their research, the authors use many sources from Rabbinic literature, from the times of Talmud through the Middle Ages until modern times. This literature has been translated from Hebrew and Aramaic to Croatian for the first time by the authors. In the article the authors show that an animal life has its own intrinsic value since it was also created by God and it is therefore not allowed to endanger it or take it without a good cause. Still, if one is forced to choose between the life of a human being and the life of an animal, the life of a human being has precedence over the life of an animal.

Key words: responsa, halacha, rabbi, animals, compassion.

(na engl. prev. Kotel DaDon)

\footnotetext{
* Agnes E. DaDon, Lektor of Hebrew languege, Chair for Judaic studies, Faculty of Philosophy, University of Zagreb; Address: Ivana Lučića 3, 10000 Zagreb, Croatia; E-mail: dadonagi@ gmail.com.

*** Kotel DaDon, PhD, Assist. Prof., Chair for Judaic studies, Faculty of Philosophy, University of Zagreb; Address: Ivana Lučića 3, HR-10000 Zagreb, Croatia; Chief Rabbi, The Bet Israel Jewish Community of Croatia; E-mail: kdadon@gmail.com.
} 